\title{
The Effectiveness of the Principle of Recovery of the Costs of Water Services Jeopardized by the European Court of Justice - Annotations on the Judgment in $\mathrm{C}-525 / 12$
}

\author{
P.E. Lindhout \\ Utrecht University \\ p.e.lindhout@uu.nl \\ H.F.M.W. van Rijswick \\ Utrecht University \\ h.vanrijswick@uu.nl
}

\begin{abstract}
In Case C-525/12 the European Court of Justice concludes that cost recovery for water services as outlined in Article 9 of the Water Framework Directive is only one of the instruments for Member States to strive for a rational water use. It furthermore concludes that the WFD environmental objectives not necessarily imply that cost recovery should be applicable to all water-related activities mentioned in Article 2 (38) WFD. In this underlying contribution a number of critical remarks to this judgment are provided. In view of the authors, the European Court of Justice reduces the effectivity of the cost recovery principle too rigorously by reducing the principle of cost recovery for water services to a practically voluntary tool for Member States.
\end{abstract}

\section{Keywords}

Cost Recovery - Polluter Pays Principle - Water Services - Article 9 Water Framework Directive - Water Uses - Economic Instruments 
In the recently decided infringement case-525/12 the European Commission (hereafter: Commission) requested the European Court of Justice (ECJ) to declare that Germany failed to fully implement its obligation according to Article 9 of the Water Framework Directive to "take account of the principle of recovery of the costs of water services, including environmental and resource costs, having regard to the economic analysis conducted according to Annex III, and in accordance in particular with the polluter pays principle." Germany has based its implementation of the cost recovery principle on a narrow interpretation of the concept of "water services" including only the classic services of water supply and waste water collection and treatment. According to the Commission the notion of "water services" must be interpreted much wider as including also the impoundment of water for the purposes of hydroelectric power generation, navigation and flood protection, abstraction for irrigation and industrial purposes and personal consumption. In its judgment, the Court of Justice has basically dismissed the Commission's action. Surprisingly, however, the Court did so without clarifying the notion of "water services". Instead, the judges held that Article 9 WFD is generally providing an ample margin of discretion as to how far Member States apply the cost recovery principle, and that infringement can only be established on the grounds that the absence of cost recovery instruments will effect a failure to achieving the ultimate quality objectives set out in Article 4 WFD. This reasoning of the Court considerably weakens the effectiveness of the cost recovery provision, and therewith cost recovery as an important instrument of water management. Therefore, this judgment deserves a critical evaluation. Before reflecting on the findings of the Court in more detail (4.) we will further introduce the substance of the dispute (2.) and the findings of the Court (3.). Questions of admissibility of the application which had also been raised by the German Government in this case will not be commented.

Substance of the Dispute

The Commission and Germany hold a different view on the interpretation of the term 'water services' as mentioned in Article 2(38) and Article 9 of the Water Framework Directive. Article 2(38) WFD states:

"water services" means all services which provide, for households, public institutions or any economic activity: 
(a) abstraction, impoundment, storage, treatment and distribution of surface water or groundwater, or

(b) waste-water collection and treatment facilities which subsequently discharge into surface water.

Article 9 WFD states, in so far as relevant:

"Recovery of costs for water services

1. Member States shall take account of the principle of recovery of the costs of water services, including environmental and resource costs, having regard to the economic analysis conducted according to Annex III, and in accordance in particular with the polluter pays principle.

Member States shall ensure by 2010:

- that water-pricing policies provide adequate incentives for users to use water resources efficiently, and thereby contribute to the environmental objectives of this Directive,

- an adequate contribution of the different water uses, disaggregated into at least industry, households and agriculture, to the recovery of the costs of water services, based on the economic analysis conducted according to Annex III and taking account of the polluter pays principle.

Member States may in so doing have regard to the social, environmental and economic effects of the recovery as well as the geographic and climatic conditions of the region or regions affected.

\section{2. (...)}

3. $(\ldots)$

4. Member States shall not be in breach of this Directive if they decide in accordance with established practices not to apply the provisions of paragraph 1, second sentence, and for that purpose the relevant provisions of paragraph 2, for a given water-use activity, where this does not compromise the purposes and the achievement of the objectives of this Directive. Member States shall report the reasons for not fully applying paragraph 1 , second sentence, in the river basin management plans."

The Commission holds the view that due to Germany's very narrow interpretation of the term water services, it is misapplying Article 9 concerning cost 
recovery. The wording of the definition of water services (Article 2(38) WFD) does not preclude the solitude activities from being a water service as, according to the Commission, a water service does not require that all in Article 2(38) listed activities should be present cumulatively. By excluding certain activities from the scope of cost recovery, Germany would be undermining the purpose of the directive. The Commission holds a broad view on water services, possibly even including ecosystem services. ${ }^{1}$

Germany, on the other hand, brings forward that cost recovery is a tool, an instrument, to contribute to the attainment of the objectives of the directive, but it is not the only one. Germany stresses the need to be able to weigh up the water protection requirements against legitimate rights of use of water, taking position that the Commission disregards the management system of the directive. Germany interprets the concept of water services very narrowly, only including the water supply and waste water treatment. It disagrees with the Commission that water services would include activities as water use for navigation or hydropower, as the concept of services would require a bilateral relationship, which is not the case with such services. Germany furthermore refers to the structure of Article 2(38) sub a. and b., which structure - according to Germany is based on a separation between activities relating to the supply of water and the treatment of waste water. Reese discusses in his paper 'Cost Recovery and Water Pricing in Water Services and Water Uses in Germany' ${ }^{2}$ the arguments for a narrow interpretation of the cost recovery obligation in more detail and states that these arguments are broadly accepted in German literature:

- 'The distinction in Article 2 sec. 38 between (a) and (b) — where (b) clearly refers to waste water services. This indicates that only supply and wastewater services are included in the notion of water services. Otherwise, that distinction would be pointless.

- The activities listed in (a) are typical activities of water supply services, and those listed in (b) typical activities of wastewater services. This, too, suggests that only these two classic services are referred to.

1 See on the consequences of a very broad interpretation of water services: P.E. Lindhout, 'A wider notion of the scope of water services in EU water law, Boosting payment for water related ecosystem services to ensure sustainable water management?', Utrecht Law Review, (2012).

2 JEEPL 10.4 (2013) 355-377. The paper is part of a special issue on cost recovery for water services and includes also contributions from the Netherlands: P.E. Lindhout, Application of the Cost Recovery Principle on Water Services in the Netherlands, JEE PL 10.4 (2013) 309-332 and Portugal: Alexandra Aragão, Water Pricing and Cost Recovery in Water Services in Portugal, JEEPL 10.4 (2013) 333-354. 
- The conjunction of the activities mentioned under (a) by "and" indicates that the legal definition can only be met by a combination of such activities (as elements of supply services).

- For important other uses like, e.g., water power, the definition and the distinction between the 1st and 2nd indent does not compute, as major activities implied by water power are either not included, or partly fall with 1st and partly with 2 nd indent.

- The same holds true for flood protection and waterways construction. Impoundment is only one activity that may serve these purposes. Otherslike dredging — are not mentioned.

- The general purposes of Article 9 and the WFD do not necessitate a wide interpretation of "water services" since the activities in question are still qualified as water uses and thus subject to equivalent pricing policies according to Article 9(1) 2nd sentence 1st indent WFD.'

These arguments are for Reese 'much more convincing than the Commission's broad interpretation'. According to Reese 'both structure and content of the definition strongly support the narrow understanding, and it cannot be simply inferred from the general teleology and/or an "effet-utile" argument that the cost recovery principle should be applied comprehensively to all encroaching activities and as far as is it can possibly contribute to the realization of the WFD's aims.' He refers to the intention of the Council when adapting the Directive and the discussions on the scope of Article 9. As a majority of Member States preferred a more conservative application of the Cost Recovery Principle he argues that the above cited arguments strongly support the narrow "German" position. As far as self-providing activities are concerned Germany takes the approach that they shall only be qualified as water services in the sense of Article 9(1) 1st sentence if they significantly affect the local water quantity balance. Important effect of this approach is that most agricultural wells have no such significant impact and must, therefore, not be qualified as "water services."

\section{Findings of the Court}

Although one might expect that the Court would provide an interpretation of the concept of water services, it does not. The Court starts by outlining its method of interpretation. Interpretation of a provision of $\mathrm{EU}$ law requires not only that the wording of the provision is taken into account, and the objectives the provision pursues, but also its context and provision of $\mathrm{EU}$ law 
as a whole. The 'travaux preparatoires' may furthermore contribute to the interpretation. ${ }^{3}$

The Court starts by outlining the two provisions concerned and ascertains that the concept of 'services' is not defined therein. In order to assess whether any service relating to the activities mentioned in Article 2(38) WFD would be subject to the principle of cost recovery the Court starts by analyzing the context and overall scheme of the provisions in question. The Court considers, based on the travaux preparatoires, that as practices in the Member States vary widely, the EU legislature intended that Member States may determine the measures to be adopted for the purposes of the application of the principle of cost recovery without extending it to all services associated with water use. The Court furthermore considers that 'in requiring in Article 9 that Member States are to have regard to the principle of recovery of the costs of water services and ensure that water-pricing policies provide adequate incentives for users to use water resources efficiently' and thereby contribute to the environmental objectives of the WFD, Article 9 'does not per se impose a generalized pricing obligation in respect of all activities relating to water use. ${ }^{4}$

As a second step in interpretation the Court examines the scope of the two provisions in the light of the objectives pursued by the WFD. It starts by noticing that the WFD is a framework directive, which provides for common principles and an overall framework for action, that Member States need to further develop. ${ }^{5}$ It does not provide for complete harmonization of the rules of the Member States concerning water. The Court furthermore considers that preamble 19 of the directive reflects the purpose of the directive, i.e. maintaining and improving the aquatic environment. ${ }^{6}$ Referring to preamble 13 of the Directive, which entails that the diverse conditions and needs in the Union are to be addressed in planning and execution of measures, which planning and measures are to be decided upon as close as possible to the locations where water is affected or used, the Court concludes that 'priority must be given to actions coming within the jurisdiction of the Member States in drawing up action program adapted to local and regional conditions. ${ }^{7}$

3 See on the increasing importance of the travaux preparatoires for interpretation: K. Lenaerts \& J. Gutiérrez Fons, 'To Say What The Law of the Eu Is: Methods of Interpretation and the European Court of Justice', AEL 2013/9.

4 C-525/12 European Commission v Federal Republic of Germany ECLI:EU:C:2014:2202, para. 48.

5 Ibid., para. 5 .

6 Ibid., para. 51.

7 Ibid., para. $5^{2}$. 
The Court further considers that the directive is based on principles of management per river basin, which the Court summarizes:

- the setting of objectives per body of water;

- plans and programmes;

- an economic analysis of the detailed arrangements governing water pricing;

- the taking in to account of the social, environmental and economic effects of cost recovery as well as the geographic and climatic conditions of the region(s) concerned.

To that end, the program of measures of the Member States, obliged by Article $11 \mathrm{WFD}$, needs, as minimum requirement, to include measures relating to the recovery of the costs for water services, such as those provided for under Article 9 of Directive $2000 / 60 .{ }^{8}$ The Court considers that cost recovery measures are 'one of the instruments available to Member States in water management to achieve rational water use. ${ }^{9}$ Even though the activities listed in Article 2(38) may undermine the achievement of objectives of the Directive, it is not necessarily so that the failure to attain the objectives is due to the absence of pricing for those activities. Lastly, the Court considers in addition that Article 9(4) WFD provides that Member States may, under certain circumstances, opt not to proceed with the recovery of costs for a given water use activity, where this does not compromise the purposes and achievement of the objectives of the WFD. ${ }^{10}$ Having outlined the above, the Court dismisses the Commission's action as the fact that Germany does not make some of the water activities mentioned in Article 2(38) subject to the principle of cost recovery for water services does not by itself establish a failure to fulfil its obligations under Articles 2(38) and 9 WFD.

This Court decision is of great importance for Member States. The Commission started on similar grounds infringement procedures against many MemberStates. ${ }^{11}$

\footnotetext{
$8 \quad$ Ibid., para. 54 .

$9 \quad$ Ibid., para. 55 .

$10 \quad$ Ibid., para. 57.

11 These are Austria, Belgium, Denmark, Finland, Hungary, the Netherlands and Sweden (European Commission, Press release IP/12/536).
} 
Not only provides this judgment (a bit more) clarity on the Court's view on the concept of water services, it also positions the function of the cost recovery provision (Article 9) within the programmatic approach on water management as included in the WFD.

The Court judgment positions cost recovery as a practically voluntary tool to be used by Member States at least offering the Member States a huge margin of appreciation. It is effectively up to the Member States, to decide in how far or even whether cost recovery is a measure to be applied for certain water uses or services. They are not obliged to. Even if the objectives of the directive are not attained, that does not mean that it is a result from a lack of pricing.

A few critical notes may be placed with this Court decision. The first critical note refers to the underlying idea of cost recovery. Its rationale is to contribute to sustainable and equitable water use by internalisation of not only financial costs of water services, but also environmental and resource costs, in water prices and to provide adequate incentives in water policy to stimulate an efficient water use. ${ }^{12}$ By this judgment the Court limits the potential effectiveness of the cost recovery provision drastically by ignoring parts of its goals. Furthermore, the program of measures each Member State needs to set up includes different measures and tools to ensure the achievement of the objectives set for the specific river basin. But if the application of cost recovery would be fully to the discretion of Member States, the inclusion of this specific economic instrument in a separate provision in the WFD results in an empty shell.

There are a number of arguments that would underline a more obligatory requirement for Member States to take cost recovery into account.

\section{The Function of the Cost Recovery Provision is not Limited to the Implementation of the Management Objectives of Article 4}

The Court of Justice seems to relate cost recovery exclusively to Article 11 WFD (programme of measures) and Article 4 WFD (environmental objectives). It is not clear what considerations underlie this point of view. In the Court's considerations regarding its interpretation it does not consider the position of cost recovery in relation to the defined purpose in Article 1 of the WFD at all. ${ }^{13}$ The purpose of the Directive is not at all included in the considerations. Besides taking into account the statements of the preamble, taking into

12 See for an extensive outline of the rationale for cost recovery: W. Howarth, 'Cost recovery for water services and the polluter pays principle', ERA Forum (2009), para. 2.

13 In other cases the $\mathrm{ECJ}$ in a contextual interpretation approach does refer explicitly to the purposes as included in the directive concerned; for example C-195/12 Industrie du bois de Vielsalm \& Cie (IBV) SA, 26 September 2013, para. 54-55. 
account the purpose of the Directive as laid down in Article 1 WFD should have been included. ${ }^{14}$ The purpose of the WFD is to establish a framework for the protection of inland surface waters, transitional waters, coastal waters and groundwater. It is a framework to which end aquatic ecosystems and their water need to be protected and enhanced. Furthermore, this framework needs to promote sustainable and equitable water use, based on a long term protection of water resources. Thirdly, the framework should ensure better protection of the aquatic environment against pollution and quality degradation. Besides, the framework is to contribute to mitigating the effects of floods and droughts. In our view, Article 9 WFD holds, besides its relation to the environmental objectives of Article 4 WFD and the programme of measures in Article 11 WFD, an independent position in relation to the purpose of the Directive, ${ }^{15}$ especially where it concerns the aim of promoting sustainable water use. Internalization of environmental costs in this respect is one of the fundamental principles, recognized internationally, to be able to reach sustainable water use. ${ }^{16}$

Furthermore, the wording of the derogation clause of Article 9(4) also implies this scope of the cost recovery provision. The derogation clause mentions the objectives of the Directive. Therefore, this provision is not limited to

14 Illustrative regarding methods of interpretation in this respect, see C-195/12 Industrie du bois de Vielsalm \& Cie (IBV) SA, 26 September 2013, (rapporteur A. Prechal), para. 54-55, where the Court of Justice, with regard to the contextual interpretation of subject and purpose of the legal act explicitly starts at the purpose as defined in the legal act. Considerations of the preamble support the interpretation of the defined purpose to that end.

15 See P.E. Lindhout 'A wider notion of the scope of water services in EU water law, Boosting payment for water related ecosystem services to ensure sustainable water management?', Utrecht Law Review, (2012); See also E. Gawel, W. Köck et al. 'Reform der Abwasserabgabe: Optionen, Szenarien und Auswirkungen einer fortzuentwickelnden Regelung' Umweltforschungsplan des Bundesministeriums für Umwelt, Naturschutz, Bau und Raktorsicherheit, Texte 55/2014, p. 89; Furthermore E. Gawel, 'Cost recovery for 'water services' / Critical review of the EU Court of Justice conclusions of Advocate General Jääskinen in case C-525/12', Europäische Wasserrahmenrichtlinie, 19 August 2014, considering: 'Rather, the responsibility for costs pursuant to Article 9 of the Water Framework Directive is a fundamental principle of order in a world of scarce resources, and as such it is an independent part of the framework of order established by the Water Framework Directive as a whole, as per Article 1 of the Directive.'

16 See Resolution of the Council of the European Communities (...) of 17 May 1977 on the continuation and implementation of a European Community policy and action programme on the environment, oJ C 139, 13.6.77, chapter 2; see regarding internalisation of environmental costs as international environmental principle: Principe 16 van de 'Rio Declaration on Environment and Development' 
the environmental objectives of Article 4 WFD and reflects much more than only 'an optional instrument' that Member States may use in their programmatic management approach and holds a strong strategic objective of its own. It is remarkable that the Court of Justice does not consider cost recovery in respect of the diversely formulated purposes of Article 1 WFD at all.

\section{(2) The 'Framework' Character of the Directive does not Preclude Addressing Cost Recovery as (Preliminary) Obligation.}

It is true that the cost recovery provision is included in a 'framework' directive. The Court considers that the character of a framework directive brings along that the directive does not intend for complete harmonization on the rules of the Member States concerning water. It states that the WFD establishes the common principles and an overall framework for action in relation to water protection and coordinates, integrates and, in a longer perspective, develops the overall principles and structures for protection and sustainable water use. These considerations, in our view, however do not conclusively lead to the position that cost recovery should be to the full discretion of the Member States to use as an environmental policy instrument. The lack of intention for complete harmonization on the rules of the Member States concerning water does not necessarily mean that no basic harmonization of elements of water rules was intended. It denies the specific inclusion of the principle of cost recovery provision in the WFD. Even though the legislative process shows divergence between the Council and Parliament on the different concept text versions regarding cost recovery, the inclusion of cost recovery as such to promote sustainable and efficient water use was not specifically debated upon. Is therefore the current, agreed upon, text of the cost recovery provision not moreover one of the first common principles? Cost recovery, by which not only financial costs but also environmental and resource costs are to be recovered and by which efficient water use is to be stimulated, is one of the policy principles of sound water management. ${ }^{17}$ The Advocate General Jääskinen, although we do not agree to his overall view, in our view rightly remarks that the integration of environmental costs is one of the fundamental principles of water management. Economization has been an important element of European environmental policy since the seventies and internalization of environmental costs can be considered an international environmental principle. ${ }^{18}$

\footnotetext{
17 Not putting a price on a scarce resource like water can be regarded as an environmentallyharmful subsidy, Blueprint, сом (2012) 673 .

18 See Resolution of the Council of the European Communities (...) of 17 May 1977 on the continuation and implementation of a European Community policy and action
} 
The Court however does not position the cost recovery provision in this setting at all. Furthermore, the fact that the Water Framework Directive has the character of a framework directive does not, in itself, mean that Member States have a great amount of policy discretion. The Water Framework Directive replaces a wide range of water directives and knows quite specific obligations for the Member States.

\section{(3) Cost recovery as Species of Economic Instruments and its Inclusion in the Program of Measures as 'Basic Measure'}

Furthermore, the Court does not seem to distinguish cost recovery from other economic instruments when examining the scope of the two provisions in the light of the objectives pursued by the Directive. And that may prove to be relevant for the scope of Article 9. The Court quotes in that respect a number of considerations in the preamble, but does not mention preamble no. (38) regarding economic instruments, which seems to be relevant in this respect. It states:

(38) The use of economic instruments by Member States may be appropriate as part of a programme of measures. The principle of recovery of the costs of water services, including environmental and resource costs associated with damage or negative impact on the aquatic environment should be taken into account in accordance with, in particular, the polluter-pays principle. An economic analysis of water services based on long-term forecasts of supply and demand for water in the river basin district will be necessary for this purpose.

'Economic instruments' is a much broader concept than cost recovery for water services. Economic instruments may include fiscal instruments like subsidies, environmental taxes, refund schemes et cetera. Cost recovery is a species of an economic instrument, specifically laid down in Article 9 WFD and therewith separated from 'economic instruments in general'. Economic instruments in general are only included in the WFD as voluntary tool to Member States. It would confirm that the principle of cost recovery is laid down as a common principle to be taken into account.

In addition, based on Article 11 WFD Member States must provide a program of measures for each river basin, which program should take account of

programme on the environment, oJ C 139, 13.6.77, chapter 2; see regarding internalisation of environmental costs as international environmental principle: Principe 16 van de 'Rio Declaration on Environment and Development' 
the results of the economic analyses of Article 5 WFD, in order to achieve the objectives as mentioned in Article 4 WFD (environmental objectives). The program of measures ex. Article 11 WFD should include the 'basic measures' of which one is 'the measures deemed appropriate for the purposes of Article 9'.

As reflected above, the use of other economic instruments is mentioned in the list of 'supplementary measures'. Economic or fiscal instruments as supplementary measure are explicitly mentioned in Annex VI - Part B. Those measures are voluntarily.

Since the Court of Justice leaves the application of cost recovery to the full discretion of the Member States, we feel that the 'reason d' être' of the specific cost recovery provision and it's indication as basic measure of a program of measures is nullified. If there is no principle to recover the costs of water services as a starter anyway, why provide a separate provision at all? Why include it (and not other economic instruments) in the list of 'basic measures'?

\section{(4) Cost Recovery Provision Limited to a Heavy Reporting Requirement?}

By interpreting the cost recovery provision in this manner, positioning it to the full discretion of Member States to use - or not use - this specific instrument in the attainment of the objectives of the WFD, the Court not only denies the difference in position of cost recovery to other (voluntary) economic instruments, but also reduces the scope of the (extensive and detailed) cost recovery provision to effectively only the requirement to 'report on the practical steps and measures taken to apply the principle of recovery of the costs of water use in accordance with Article 9 WFD' in the program of measures. ${ }^{19}$ It reduces the potential effectiveness of the cost recovery provision to an administrative burden. It makes it even harsher when one considers that there seems no sanction possible to non-application of cost recovery in a programmatic approach, because - as the Court worded - 'the absence of pricing will not necessarily jeopardize the attainment of the Directive's objectives'. Exactly because the last is true and the Court of Justice in addition limits cost recovery to the program of measures and environmental objectives instead of also the purpose of the directive itself, it should be preferred to position the cost recovery provision more strongly in its principle obligation (take into account cost recovery and in so doing consider also social, economic, environmental and certain

19 The river basin management plans, as referred to in Annex VII sub 7.2 of the Directive, should contain 'a report on the practical steps and measures taken to apply the principle of recovery of the costs of water use in accordance with Article 9.' 
other aspects). Now the provision seems to be reduced to not more than an empty shell.

\section{(5) A Derogation Clause in Article 9 (4) WFD without Substance?}

The Court refers furthermore to the derogation clause of Article 9(4) WFD when considering that water activities as mentioned in Article 2 (38) WFD may undermine the achievement of the Directive's objectives. It considers:

it cannot be inferred therefrom that, in any event, the absence of pricing for such activities will necessarily jeopardize the attainment of those objectives. In that regard, Article 9(4) of Directive 200o/6o provides that the Member States may, subject to certain conditions, opt not to proceed with the recovery of costs for a given water use activity, where this does not compromise the purposes and the achievement of the objectives of that directive. It follows that the objectives pursued by Directive 2000/6o do not necessarily imply that Article 2(38)(a) thereof must be interpreted as meaning that they all subject all activities to which they refer to the principle of recovery of costs, as maintained in essence by the Commission. ${ }^{20}$

The Court refers to the derogation clause as a 'no longer proceed with cost recovery' clause. Non proceeding with cost recovery would be only allowed if it does not compromise the purposes and the achievement of the objectives of the directive.

The considerations of the Court, however, reduce also the derogation clause to almost an empty shell as the Court first stresses that cost recovery is not - not even by means of principle - necessarily applicable to the water activities as mentioned in Article 2 (38) WFD. The Court considers in this respect that the objectives of the Directive would not imply such applicability. Secondly, the Court considers that even if activities mentioned in Article 2 (38) WFD in themselves may be undermining the achievement of the Directive's objectives, that does not bring about that any lack of pricing of those activities will necessarily jeopardize the attainment of the objectives. Thirdly, as outlined before, it seems that the Court has considered that what actions to be included in a program of measures is to the full discretion of the Member States. This approach results in a derogation clause of Article 9 (4) WFD which seems rather redundant, as there is no main obligation to apply cost recovery (not even to a minimum extent). It will, due to these

20 C-525/12 Commission vs Federal State of Germany ECLI:EU:C:2014:2202, para. 56-57. 
considerations, be very difficult to sufficiently state and prove that a Member State has applied the derogation clause not legitimately. This is even harsher when one considers that derogation clauses are to be interpreted in a strict manner. ${ }^{21}$ What is left to be considered in a strict manner in the derogation clause after this judgment seems rather questionable.

Final reflection: A more obligatory character still offers MS enough discretionary room for tailor-made solutions and acknowledges the specific inclusion of cost recovery in a separate legal provision

When considering the above, the question arises whether the interpretation of the Court of Justice to leave the application of cost recovery to the full discretion of the Member States is the only plausible interpretation that is in line with and/or serves the wording of the provision and complies with the context and coming about of the provision. As outlined in this annotation there are many arguments to interpret the cost recovery provision differently and in a more strict manner. If a more strict obligatory character of the provision would be embraced, the fundamental principle of internalization environmental costs is met, the derogation clause of Article 9 (4) will be substantial and still tailor-made solutions are possible in Member States' water management strategies. The cost recovery provision offers Member States still enough discretionary room to take into account specific circumstances in the river basin concerned. The provision states to this end that Member States 'in so doing', i.e. in recovering the costs as mentioned in Article 9, may take into account the social, environmental and economic effects of the recovery as well as the geographic and climatic conditions of the region or regions affected. This more strict approach would be (better) in line with the wording of the provision and the objectives it pursues, without putting it out of context or mismatching the provisions of EU law otherwise. ${ }^{22}$ Where different interpretations of a provision of EU law are possible, preference should be given to that interpretation which ensures that the provision retains its effectiveness. ${ }^{23}$ It would

21 C-14/06 and C-295/o6 European Parliament and the Kingdom of Denmark vs Commission of the European Communities, ECLI:Eu:C:2008:176, paras. 71-75; C-57/94 Commission of the European Communities vs Italian Republic, ECLI:EU:C:1995:150, para. 23; C-375/05 Geuting ECLI:EU:C:2007:574, para. 52.

22 See forthcoming P.E. Lindhout, Cost recovery as a policy instrument to achieve sustainable and equitable water use in Europe and the Netherlands, Utrecht University, PhD Thesis, expected 2015 .

23 C-187/87 Saarland a.o., ECLI:Eu:C:1998:439, para. 19; C-434/97 Commission v France, ECLI:EU:C:2000:98, para. 21; C-402/07 and C-432/07 Sturgeon a.o., ECLI:EU:C:2009:716, para. 47 . 
maintain the provision's effet utile, without crossing the contextual borders. ${ }^{24}$ The Member States can find the necessary flexibility in the stipulation that they may take into account the social, environmental and economic effects of the recovery and the geographic and climatic conditions in the specific area. The programmatic approach can still be applied, albeit that cost recovery for water services is a sincere starting point, a common and in the legislative history agreed upon principle to be truly taken into account.

24 Lenaerts \& Gutiérrez Fons consider in respect of a contextual interpretative approach by the ECJ: 'This means that each provision of EU law must be interpreted in such a way as to guarantee that there is no conflict between it and the general scheme of which it is part. As a token of rationality, the EU legislater must also avoid useless duplication. Accordingly, no provision of Eu law should be redundant. Instead, each and every provision of law must be interpreted in light of its 'effet utile'; K. Lenaerts \& J. Gutiérrez Fons, 'To Say What The Law of the EU Is: Methods of Interpretation and the European Court of Justice', AEL 2013/9, p. 14 . 